ISBN 978-81-936279-5-2

12th International Conference on Business, Education, Humanities and Interdisciplinary Studies

(BEHIS-18)

Zagreb (Croatia) May 11-12, 2018

\title{
The Service Quality of the Government Savings Bank Phaholyothin
}

\author{
Puttipong Manosuttikij and Asst. Prof. Suthum Phongsamran \\ Gaduate School of business administration, Kasembundit University, Bangkok, Thailand
}

\begin{abstract}
Studying the service quality of the Government Savings Bank PhaholyothinThe objectives of this research were to study factors of service quality and service satisfaction of Savings Bank. Phaholyothin Use questionnaire as a tool to collect data. The sample used in the study was the Savings Bank user Phaholyothin 385 person. Data were analyzed by means of descriptive statistics, percentage mean and data analysis to test the hypothesis. T-test statistics, F-test (ANOVA), statistics on relationship between variables by Regression Analysis Most respondents are women aged 20-30 years. Occupation Income between 15,000 - 20,000 Baht Single statuses 1-3 times per month. And use the deposit transaction.Quality of service the ability to touch. Reliability.

The response to the needs of the recipient. Confidence and access to the soul of the user. Satisfaction was at a high level. The response to the needs of the service, the most. And satisfaction in service quality. Very highSuggestions from the study Management Savings Bank should improve technology.Modern equipment Create image through online and offline media to give users more trust. Encourage employees to work more.For example, there are special remunerations available to meet certain criteria. It ensures customers in the security system in the property.

The service is of international standard and emphasizes the communication between staff, service providers and users to make the service faster and more impressive.
\end{abstract}

Keywords: Quality, Service, Satisfaction

\section{Introduction}

Customer service is at the heart of making a difference in the business to keep the consumer in mind. Therefore improving service quality is important. To provide excellent service and Can be superior to competitors. The organization has tried to improve and improve service quality. To become a bank in the hearts of the people. According to the vision of the bank. The bank should provide training to service staff. Property updates Improve business services. To customers who come to the service impressed with the service.

So it is seen that the savings bank. Phaholyothin Focus on Quality of service is great. Whenever customers feel good and impressed with the service they receive. Then the customer will be satisfied and return to service again. It also tells the person to close as well. That's the point. "The heart of true service. The quality of service that can impress the service recipient (Chittinan Decha Gupta BE.2543: 60)

The competition of financial institutions is more intense. The Savings Bank Phaholyothin More attention to service. We aim to develop service excellence. The quality and the kindness (Supachanan \& Khunkaew and Yuttana Nuchprayoon, 2007).

Therefore, from the reasons and competitive situation of the banking business mentioned above. Researchers have recognized the importance of quality of service and in keeping with the bank's strategy. It is interesting to do research. 
The service quality of the Government Savings Bank Phaholyothin the results of this research will be beneficial to the Bank's operations. The results of the study. This is a guideline to consider, improve, and develop a more efficient service strategy.

To respond to customers' satisfaction, they can compete with other commercial banks and improve the capacity of their employees.

\section{Purpose of study}

1. To study the quality of services of the Government Savings Bank Phaholyothin

2. To study the satisfaction of the service of the Government Savings Bank. Phaholyothin

3. To study the relationship between the quality of service and the satisfaction of the service of the Government Savings Bank. Phaholyothin

\section{Scope of Research}

1. The content of the Parasuraman concept is based on the ability to touch. Reliability The response to the needs of the recipient of the confidence. Access to the mind of others. And satisfaction in service.

2. Scope of population and sample of citizens are the users of GSB. Phaholyothin The sample size was 385 persons.

\section{The Benefits of Research.}

1. To know the quality of services of the Government Savings Bank. Phaholyothin

2. Make satisfaction in the service of the Government Savings Bank. Phaholyothin

3. To know the quality of services that affects the satisfaction of the service of the Government Savings Bank. Phaholyothin

4. Bring the information from the study as a guideline to improve the quality of service to the users of the Government Savings Bank. Phaholyothin Office for the highest satisfaction.

\section{Assumptions of the Study}

1. Different personal factors affect the satisfaction of the service of the Government Savings Bank. Different Phahonyothin office

2. Quality of Service of Government Savings Bank PhaholyothinRelationship with satisfaction.Service of Government Savings Bank

\section{Theoretical Concepts and Related Literature}

- Quality of service

Parasuraman has defined the quality of service as the difference between the customer's expectations for service and the perception of service, and has created a tool called SERVQUAL. There are 5 aspects.

1. The ability to touch. (Tangibility)

2. Reliability (Reliability

3. The response to the needs of the recipient. (Responsiveness)

4. Assurance (Assurance)

5. Empathy 


\section{Conceptual Framework in Education}

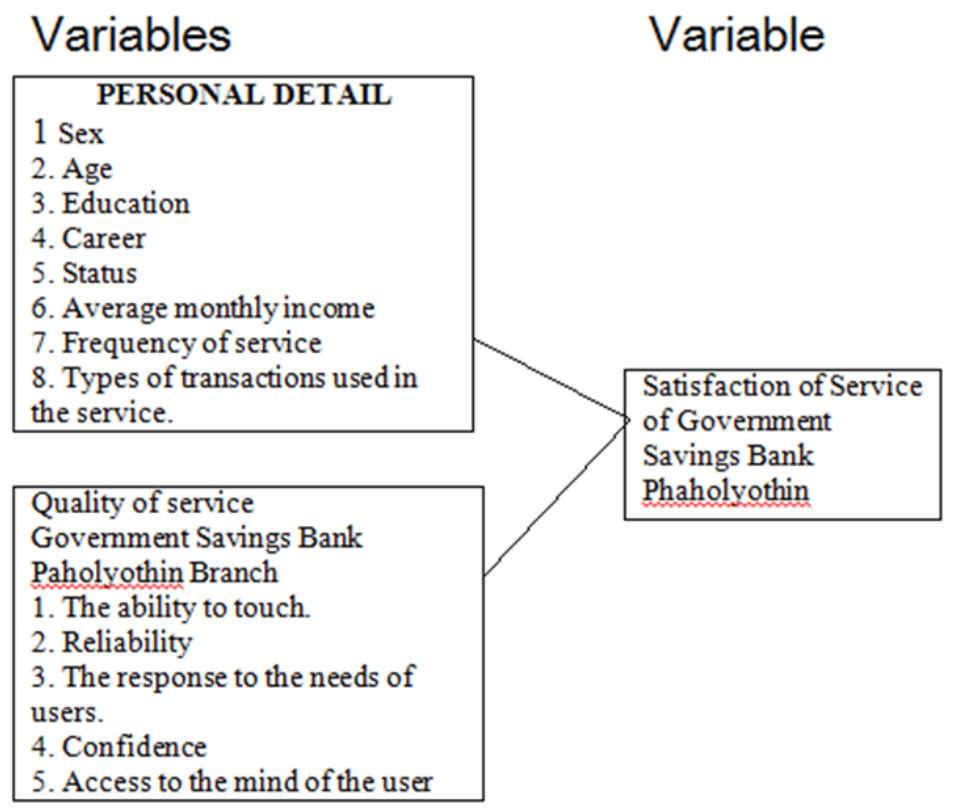

\section{Research Methodology}

Use quantitative research and use questionnaires as tools. To collect information on the savings bank customers. Phaholyothin

\section{Data Analysis}

The data obtained from the questionnaire was analyzed by computer program. Percentage and Mean were used to generate Pie Chart and Bar Chart and analyze the data to test the hypothesis. T-test, F-test (ANOVA). Use Pearson product moment correlation (Pearson product moment correlation)

\section{Study Results of Personal Information.}

The majority of respondents were female, aged 20-30 years. Occupation Income between 15,000 - 20,000 Baht Single statuses 1-3 times per month. And most transactions on deposits.

- Information about the quality of service of the Government Savings BPhaholyothin The ability to touch. From the study, it was found that the overall mean of the factors influencing the service of the Savings Bank Phaholyothin 5 levels. Contains equipment, equipment and technology standards. The conveniences of accessing the Government Savings Bank, Phaholyothin Branch, Savings Bank employees are knowledgeable in serving the Government Savings Bank. Fast service in sequence.

- Reliability From the study, it was found that the overall mean of the factors influencing the service of the Savings Bank Phaholyothin In the high level 5Composition The amount of equipment, equipment and technology is sufficient to accommodate the large number of users. The Government Savings Bank, Phahon Yothin Branch has enough space to accommodate a large number of users per day. The Savings Bank employees are loyal to the customers who use the services related to their financial transactions. The documents used in the service are stored and secured in sequence.

- The response to the needs of the recipient. From the study, it was found that the overall mean of the factors influencing the service of the Savings Bank The Phahonyothin office was at the high level of 5 items. Be enthusiastic about service. To meet the needs of users in a timely manner. Full time service And wait for the last user to complete the service willingness. The service of financial transactions is accurate. The Government Savings Bank can respond correctly to customers. All of the service. 
- Confidence From the study, it was found that the overall mean of the factors influencing the service of the Savings Bank Phaholyothin At the high level, 5 items consisted of Deposit with the Savings Bank Be safe Government Savings Bank is ready to serve. The Savings Bank staff is knowledgeable in providing advice and service. The cost of financial transaction or credit Government Savings Bank has a systematic work order.

- Access to the mind of the user. From the study, it was found that the overall mean of the factors influencing the service of the Savings Bank Phaholyothin At the high level, 5 items consisted of The Savings Bank employees are committed to work in every service. The Government Savings Bank Paholyothin can respond to problems or recommendations from the users. The Savings Bank employees are interested in listening to their problems and offering solutions. You always get a satisfactory answer from the staff. The communication of the Savings Bank employees is impressive.

A study of service quality factors affecting service satisfaction.

\section{Test Results Hypothesis}

Based on the hypothesis test 1, the results showed that personal factors were gender, age, education level, occupation status Average Frequency of Service Service Transaction The difference in the quality of services of the Savings Bank. The Phahonyothin office is not different.Personal factors with monthly income vary. Affecting the Satisfaction of the Government Savings Bank. Phaholyothin office is different.The income of 20,001-25,000 baht affect the quality of service of the Government Savings Bank. The Phahonyothin office is different from the income of less than 15,000 baht and income of 15,000-20,000 baht and the income of 25,00130,000 baht at the significant level of 0.05 .

The hypothesis test 2 shows the relationship between the service quality factors of the Savings Bank. Phaholyothin Office with Service Satisfaction of Government Savings Bank Found that the reliability. The correlation coefficient $(\mathrm{r})$ is 0.602 . The correlation coefficient $(\mathrm{r})$ was 0.554 . The correlation coefficient $(\mathrm{r})$ was 0.500. The correlation coefficient (r) was 0.493 and confidence The correlation coefficient (r) was 0.420 , respectively.

\section{Discussions}

- The study of service quality of the Government Savings Bank Phaholyothin The participants discussed the following issues. The ability to touch. When the quality of service, the ability to touch the ability to increase. The service satisfaction of the GSB increased at a moderate level, that is, when the quality of the contact services was enhanced.

In the deposit with the savings bank. Safe and ready to serve. Employee Savings Bank Knowledge The ability to provide advice and service. And there is a systematic work. Can say that. Employees understand the problems of customers and can solve problems for customers. And know the needs of customers. The customer satisfaction in the service. In line with the research results of pawina ckocsan (BE2552) Researched The quality of service of the Government Savings Bank, Sriracha Branch, Sriracha, Chonburi The study indicated that The quality of service of the Government Savings Bank, Sriracha Branch, Sriracha, Chonburi Overall service quality is good. By the responsibility. Quality is the number one service. The staff is enthusiastic about the service. Provide customer service with willingness. And with speed. Every time I use the service.

- Reliability when the quality factor of service reliability increases. The service satisfaction of GSB increased moderately.That is when the quality of service is improved. The Savings Bank employees The commitment to work. In every service. Can respond to problems or recommendations from users. Savings Bank 
Employees Interested to listen to the problem of the user and propose solutions. The users are usually satisfied with the service.

And communication of the employees of the Savings Bank. Have a quick impression. Can say that. Competent staff It introduces the right service and meets the needs of customers. It will make customers feel confident and satisfy the service. This is consistent with research by Chontisa Sribumrung (BE2557). Quality of service of Bangkok Bank Don Chonburi province The study indicated that The user has a level of feedback. Quality of service of Bangkok Bank Don The reliability of the bank. The overall picture is good. This may be due to the Bangkok Bank service. Don Can be provided on time. Service providers can provide advice or solve problems. The process of transactions to the customer correctly. The service provider can answer questions. Or provide knowledge in various areas.

- The response to the needs of the recipient. When the quality factor of the service response to the needs of the service increase. The satisfaction of service provision of GSB increased at a moderate level. When increasing the quality of service to meet the needs of the recipient. The equipment, equipment and technology are standardized. Comfort in service. The staff is knowledgeable in the service. Branch size is standard. And the speed of service. Can say that. Modern equipment and tools make the customer comfortable to use. This helps to reduce transaction time each time. And the knowledgeable staff will provide you with fast service to satisfy your customers. In line with Chontisa Sribumrung's research (BE2557) Researched Quality of service of Bangkok Bank Don Chonburi province The study indicated that Subscribers have a level of opinion on the quality of Bangkok Bank's services. Don The intention is to serve quickly with a good level. This may be due to the Bangkok Bank service. Don Be eager to service with a sufficient number of service providers. There is also a growing number of service providers.

- Confidence When the quality factor of the service of confidence increased. The satisfaction of service provision of GSB increased at a moderate level. When adding quality assurance services. The importance of employees Savings Bank. To be honest with customers who use the service. The system. Related to financial transactions of users. Be safe And the documents used in the service are stored and secure. Can say that.When the service staff is honest with the customer and the equipment of the bank is safe. The service will be provided to customers and customers will be satisfied with the services provided by the Bank. In accordance with the research of jantana pasungkit (BE2552)Researched The service quality of Bank of Ayudhya Public Company Limited Laem Chabang Branch. The samples were of the opinion that quality of service provided the customers with the highest quality of service. It was found that the use of the service. The quality of service is the best.

Access to the mind of the user. When the service quality factor of access to the mind of the user increases. The increase in the quality of service access to the mind of the users. The importance of employees Savings Bank. Be enthusiastic about service. To meet the needs of users in a timely manner. Full time and wait for the last user to complete the service willingness. Providing financial a transaction service is accurate and responsive to customers. All aspects of the service. Can say that. The staff is enthusiastic. Caring for service and prompt service. The customer satisfaction in the service. This will allow customers to re-use the service and may cause customers to tell their friends or relatives. In line with Chontisa Sribumrung's research (BE2557) Researched Quality of service of Bangkok Bank Don Chonburi province The study indicated that Subscribers have a level of opinion on the quality of Bangkok Bank's services. Do not worry about the quality of the service.From the staff listening to the problem. And suggestions and are ready to be updated as per customer requirements. As well, the service provider offers products / services that meet the needs of the customer.

\section{Suggestions from the Study Results.}

1. The ability to touch. Management Savings Bank should develop technology. Modern equipment To create a fast and convenient service to people who use the service. 
2. Reliability Executives of the Savings Bank should create image through online and offline media in order to provide more trust to the users.

3. The response to the needs of the recipient. The Savings Bank executives should create more motivation for their employees. For example, there are special remunerations available to meet certain criteria.

4. Confidence The Savings Bank executives should ensure that their customers are more secure in their property and services.

5. Access to the mind of the user. The Savings Bank Executive should focus on communicating between staff, service providers and users to make the service faster and more impressive.

\section{References}

[1] Kittitich imwattanakul (BE2553) "Public satisfaction with structural service" Fundamentals of Sub-district Administration Organization in Non-Thai District, Nakhon Ratchasima” Province: Master of Engineering Program Construction Management and Infrastructure Civil Engineering Department of Engineering University of Technology, Suranaree.

[2] Kalya wanicbuncha (BE2550) "Using SPSS for windows to analyze data"New York: Chulalongkorn University Book Center.

[3] Jitsupa chanasungkam (BE2555) "Quality Tax Service Case StudyNong Irun Subdistrict, Banbueng District, Chonburi Province" ManagementResources for security (Burapha University)

[4] Chancawan aurawongsupatug (BE2555). Quality service : Academic perspective [Online], accessed from: http: //www.tpa.or.th/

[5] Chuppong yamoteg (BE2555). The quality of transportation service of Panthong Tran Sports: MBA South East Bangkok College

[6] Kotler. (2003). Marketing management. New Jersey: Prentice-Hall

[7] Philips Corssby. (1979). Quality is Free. New York: McGraw - Hill.

[8] Parasuraman et al. (1988). Delivery Quality Service: Balancing Customer Percrptions and Expectations. New York: Free Press.

[9] Salkind, Neil J. (2000). Exploring research. Upper Saddle River, NJ: Prentice-Hall, Inc. 